\title{
PKM PENINGKATAN KUALITAS KETERAMPILAN BAGI ANAK-ANAK PANTI PELAYANAN SOSIAL ANAK "TARUNA YODHA" DI SUKOHARJO
}

\author{
Susilaningsih dan Rian Rokhmat Hidayat \\ Fakultas Keguruan dan Ilmu Pendidikan Universitas Sebelas Maret, Jl. Ir. Sutami No.36A, \\ Surakarta, 57126, Indonesia \\ Pusat Pengembangan Kewirausahaan LPPM Universitas Sebelas Maret, Jl. Ir. Sutami No.36A, \\ Surakarta, 57126, Indonesia \\ Email: susi_uns@yahoo.com
}

\begin{abstract}
ABSTRAK
Peran panti sosial anak sangat dibutuhkan sebagai pilihan untuk memberikan pelayanan kesejahteraan bagi anak putus sekolah. Panti Pelayanan Sosial "Taruna Yodha" Sukoharjo merupakan salah satu Unit Pelaksana Teknis Dinas Sosial Provinsi Jawa Tengah yang melayani 150 anak secara gratis. Alokasi biaya hanya cukup untuk memenuhi kebutuhan hidup dan kegiatan selama tinggal di asrama. Sehingga masih diperlukan tambahan biaya untuk memandirikan anak serta meningkatkan kualitas keterampilan anak. Metode yang digunakan untuk membantu mengatasi persoalan-persoalan yang telah disepakati di atas adalah pelatihan sistem budidaya pertanian, bantuan dukungan alat, dan pendampingan. Kegiatan ini dilakukan untuk meningkatkan kualitas keterampilan bagi anak-anak PPSA “Taruna Yodha" Sukoharjo sehingga dapat digunakan sebagai bekal untuk memperbaiki kualitas hidupnya. Kabupaten Sukoharjo mempunyai potensi yang tinggi di bidang pertanian. Kegiatan ini bekerjasama dengan pemilik usaha "Tarinbel Hydrofarm" selaku Mitra II sehingga dapat terjadi simbiosis mutualisme antara Tarinbel Hydrofarm dengan PPSA "Taruna Yodha" dimana bisa menjadi penyedia perlengkapan selama pelatihan serta distributor hasil tanam.

Kata kunci: Keterampilan, Anak Putus Sekolah, Taruna Yodha, Hidroponik
\end{abstract}

\begin{abstract}
The role of children's social care institutions is very much needed as an option to provide welfare services for school dropouts. "Taruna Yodha" Social Service Institution Sukoharjo is one of the Central Java Provincial Social Service Technical Implementation Units that serves 150 children for free. Allocation of costs is only enough to fulfill life needs and activities while staying in a dormitory. So that additional costs are still needed to protect children and improve the quality of children's skills. The method used to help overcome the problems agreed upon above is training in agricultural cultivation systems, tool support assistance, and mentoring. This activity was carried out to improve the quality of skills for the children of PPSA Sukoharjo "Taruna Yodha" so
\end{abstract}


that they could be used as provisions to improve their quality of life. Sukoharjo Regency has high potential in agriculture. This activity is in collaboration with business owners "Tarinbel Hydrofarm" as Partner II so that mutualism symbiosis can occur between Tarinbel Hydrofarm and PPSA "Tarod Yodha" which can be a provider of equipment during training and distributor of crop yields.

Key words: Skills, Drop Outs, Tarun Yodha, Hydroponics

\section{PENDAHULUAN}

Putus sekolah merupakan seseorang yang tidak dapat menyelesaikan pendidikan atau berhenti bersekolah dalam suatu jenjang pendidikan sehingga belum memiliki tanda tamat belajar pada jenjang pendidikan tersebut. Berdasarkan data dari Badan Koordinasi KB Nasional Pusat, hingga tahun 2009 di Indonesia terdapat 13.685.324 anak yang putus sekolah. Sebanyak 419.940 atau $32 \%$ di antaranya berada di Provinsi Jawa Tengah. Jawa Tengah menempati peringkat ke 2 dari 10 besar daerah dengah kasus putus sekolah paling tinggi di Indonesia. Dari data BPS Jawa Tengah (2016), presentase penduduk Indonesia usia 7-24 tahun menurut jenis kelamin, kelompok umur sekolah dan partisipasi sekolah sebanyak 28,13\% tidak melanjutkan sekolah ke jenjang yang lebih tinggi. Melihat kondisi tersebut, peran panti panti sosial anak sangat dibutuhkan sebagai pilihan untuk memberikan pelayanan kesejahteraan anak dengan cara mengasuh, mendidik, membimbing, mengarahkan, memberikan kasih sayang serta memberikan ketrampilan-ketrampilan yang dapat menjadi bekal masa depan.

Panti Pelayanan Sosial "Taruna Yodha" Sukoharjo merupakan salah satu Unit Pelaksana Teknis Dinas Sosial Provinsi Jawa Tengah yang bertugas memberikan bimbingan fisik, mental, sosial dan keterampilan kerja bagi anak-anak putus sekolah di Jawa Tengah tanpa dipungut biaya. Keterampilan kerja yang sudah diberikan antara lain seperti salon, bengkel sepeda motor, las, jahit, tata boga dan operator komputer. Dalam 1 (satu) tahun panti sosial ini melayani 150 anak, yang terbagi dalam 2 (dua) angkatan. Angkatan 1 bulan Januari s/d Juni, dan angkatan II bulan Juli s/d Desember. Anak-anak bimbingan panti sosial ini diharuskan tinggal di asrama selama 6 (enam) bulan. Biaya operasional yang dikeluarkan oleh Panti Pelayananan Sosial Anak "Taruna Sosial" Sukoharjo tidak sedikit. Biaya yang sudah dialokasikan oleh panti pelayanan sosial tersebut hanya cukup untuk memenuhi kebutuhan hidup anakanak selama tinggal di asrama serta membiayai kegiatan yang telah diberikan oleh panti. Sehingga masih diperlukan tambahan biaya lebih untuk memandirikan anak, memajukan kualitas pelayanan panti tersebut serta meningkatkan kualitas keterampilan anak Panti Pelayanan Sosial Anak "Taruna Yodha" Sukoharjo.

Sukoharjo merupakan salah satu kabupaten di Provinsi Jawa Tengah yang mempunyai potensi dibidang 
pertanian. Akan tetapi alih fungsi lahan pertanian menjadi perumahan mewah, gedung-gedung mewah serta kios-kios untuk berdagang membuat lahan pertanian semakin sempit di Kabuputen Sukoharjo. Sehinggu perlu terobosan baru dalam bidang pertanian dengan melihat kondisi tersebut. Hidroponik merupakan salah satu teknik budidaya tanaman (buah, bunga, sayur,dll) dengan memanfaatkan air dan tidak menggunakan tanah sebagai media tanamnya. Cara bercocok tanam hidropnik saat ini semakin banyak digemari oleh banyak orang karena tidak memerlukan lahan yang luas serta peralatan dan perlengkapan yang rumit. Peluang bisnis tanaman hidroponik sangat menjanjikan kedepannya. Oleh karena itu tim pengabdi akan memberikan pelatihan cara bercocok tanam hidroponik kepada anak-anak Panti Pelayanan Sosial Anak "Taruna Yodha" Sukoharjo dengan melihat prospek serta peluang usaha hidroponik kedepan yang akan semakin tinggi.

Pengabdian ini dilakukan untuk meningkatkan kualitas keterampilan bagi penerima manfaat Panti Pelayanan Sosial Anak "Taruna Yodha" Sukoharjo melalui pelatihan tatacara tanam hidroponik dengan memanfaatan lahan pekarangan yang tersedia di lingkungan panti tersebut. Harapan kedepan, keterampilan yang diberikan ini dapat digunakan oleh anak-anak panti tersebut sebagai bekal mereka dalam meningkatkan taraf hidup mereka masing-masing.

Kegiatan ini juga selanjutnya akan melibatkan tenant PPKwu yang merupakan pemilik usaha Tarinbel
Hydrofarm. Tenant ini adalah supplier bahan-bahan pertanian dengan system hidoponik di Sukoharjo. Melalui pengabdian ini, diharapkan terjadi simbiosis mutualisme antar tenant Tarinbel Hydrofarm dengan Panti Pelayanan Sosial Anak "Taruna Yodha" dimana bisa menjadi penyedia perlengkapan selama pelatihan serta distributor hasil tanam.

\section{METODE}

Metode pelaksanaan kegiatan ini meliputi beberapa tahapan kegiatan, yaitu:

1. Pelatihan

Pelatihan in class dilakukan untuk meningkatkan pemahaman para peserta dalam teknik budidaya tanaman maupun motivasi berwirausaha serta peningkatan keterampilan teknis pengoptimalan lahan pekarangan melalui budidaya hidroponik.

2. Pemberian Stimulan Modal

Stimulan modal yang diberikan berupa stater kit dan instalasi hidroponik.

3. Monitoring Evaluasi

Evaluasi pelatihan mencakup dua aspek yaitu evaluasi hasil dan evaluasi proses. Evaluasi hasil dilakukan dengan tujuan untuk mengetahui tingkat pengusaan pengetahuan para peserta terhadap manajemen usaha sebagaimana yang telah dilatihkan. Evaluasi proses dilakukan dengan tujuan untuk mendapatkan umpan balik dari penyelenggaraan pelatihan 


\section{HASIL DAN PEMBAHASAN}

Pengabdian masyarakat ini diawali dengan koordinasi awal dari tim pengabdi dengan mitra.

\subsection{Koordinasi}

Koordinasi awal dilakukan pada tanggal 15 Mei 2018 di Kantor PPKwu LPPM UNS pada pukul 13.00 WIB. Rapat koordinasi ini dihadiri oleh tim pengabdi dan perwakilan dari PPSA "Taruna Yodha" yang menhasilkan teknis rencana kegiatan selanjutnya.

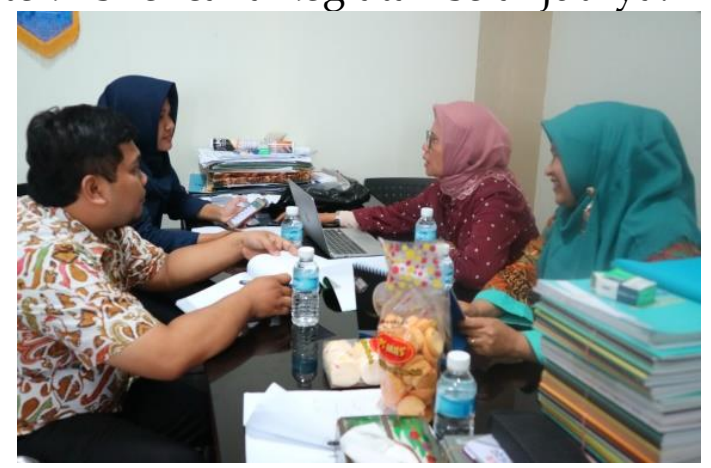

Gambar 1. Rapat Koordinasi dengan Tim Pengabdi

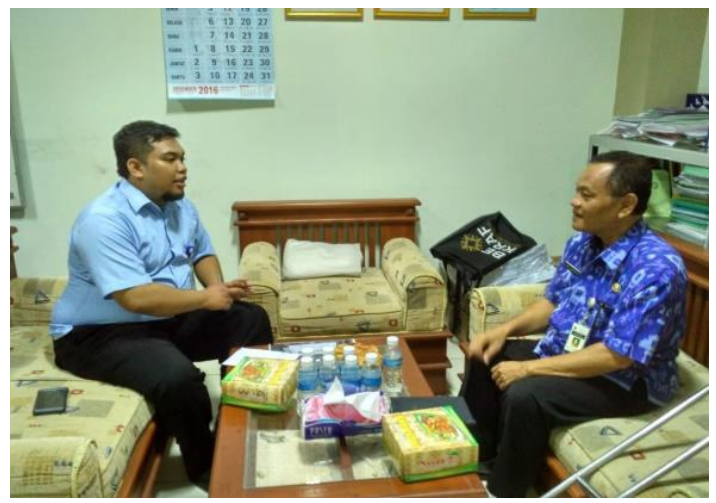

Gambar 2. Rapat Koordinasi Awal dengan PPSA “Taruna Yodha”

Dari hasil yang ditemukan mengenai permasalahan mitra, maka tim pengabdi mulai membuat proposal kegiatan pengabdian dan diharapkan mitra dapat terbantu. Kegiatan yang akan dilakukan berupa pelatihan pendampingan usaha, dan pemberian stimulan modal berupa TTG.

\subsection{Persiapan Pelatihan}

Sebelum dilakukan pelatihan, tim pengabdi mengadakan rapat terlebih dahulu untuk mempersiapkan bahan yang digunakan pada saat pelatihan berlangsung. Koordinasi persiapan pelatihan dilaksanakan pada tanggal 10 Juli 2018. Dalam koordinasi ini menghasilkan teknis pelaksanaan kegiatan pelatihan.

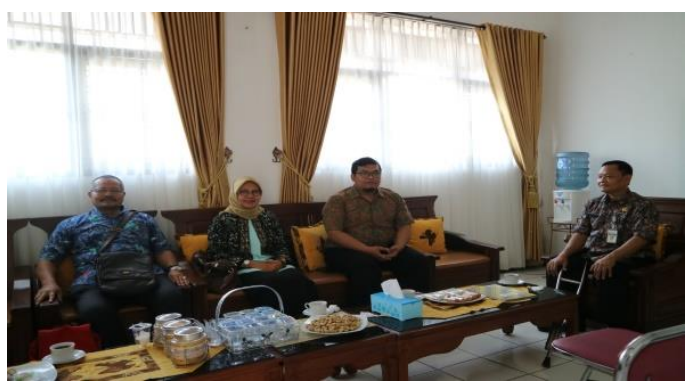

Gambar 3. Koordinasi Persiapan Pelatihan

\subsection{Pelatihan}

Pada pengabdian masyarakat ini dilakukan kegiatan pelatihan in class. pelatihan In-Class dilaksanakan pada 30 Agustus 2018 di lantai 2 Aula PPSA "Taruna Yodha" Sukoharjo. Kegiatan pelatihan diawali dengan pemberian materi tentang kewirausahaan. Pelatihan ini meningkatkan motivasi anak-anak PPSA untuk menjadi wirausaha setelah mereka lulus, sebanyak $8 \%$ anak-anak memiliki motivasi yang sangat tinggi, dan $85 \%$ menunjukkan motivasi berwirausaha tinggi. 


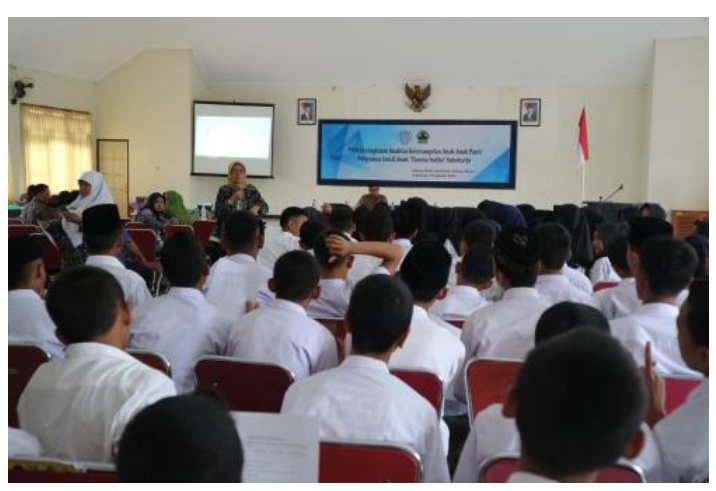

Gambar 4. Penyampaian Materi Motovasi Berwirausaha

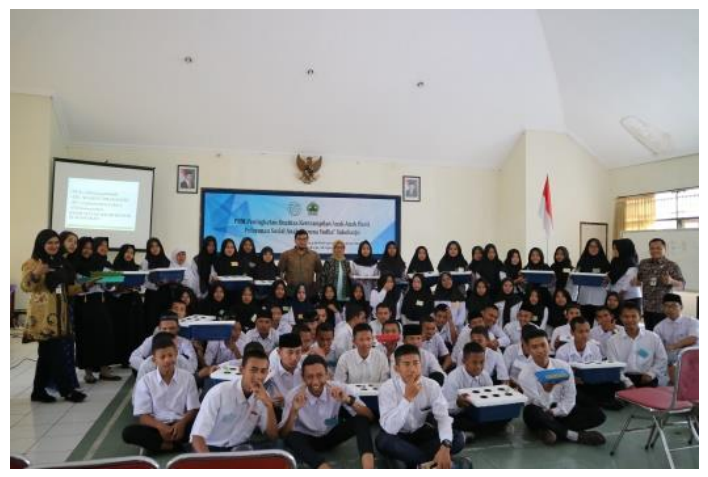

Gambar 5. Pelatihan In-class

Pada pelatihan ini juga disampaikan materi antara lain adalah penyemaian bibit yang akan di tanam. Bibit yang disemai antara lain adalah bayam merah, pakcoy, kangkung, selada dan sawi sendok.

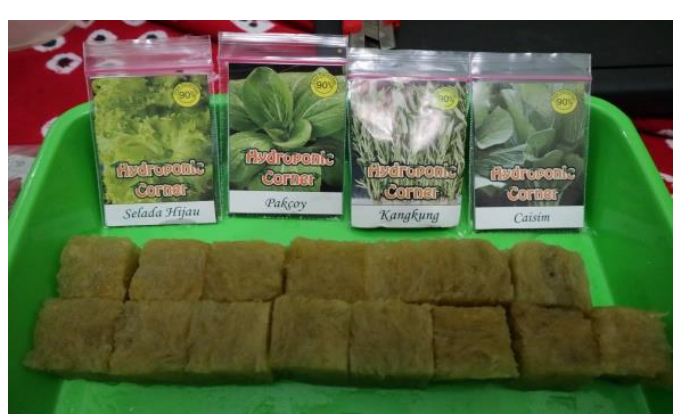

Gambar 6. Bibit yang akan disemai

Antusiasme peserta terlihat dari banyaknya peserta yang menanyakan hal - hal terkait penyemaian bibit. Tim pengabdi juga telah memberikan materi untuk bahan bacaan para peserta sosialisasi, apabila peserta mengalami kesulitan maka tim pengabdi bersedia melayani konsultasi via telepon atau chating.

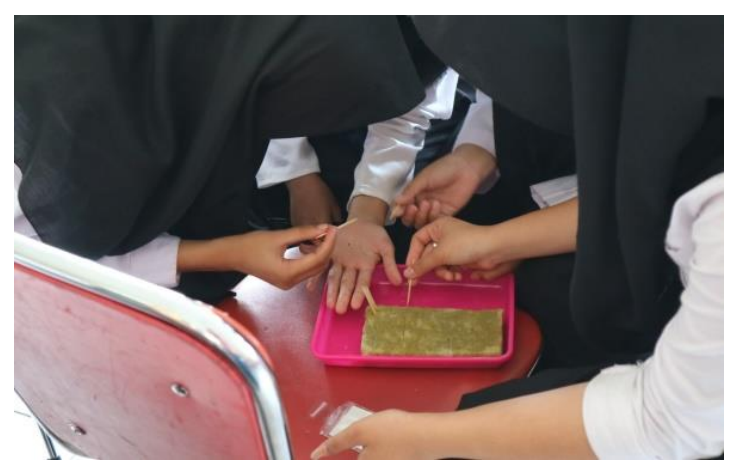

Gambar 7. Proses Penanaman Bibit ke Media

Selain penyemaian bibit, pelatihan ini juga memberikan materi tentang formulasi nutrisi tanam. Perwakilan peserta diminta untuk mendemonstrasikan formulasi nutrisi di depan teman-temannya dengan dibimbing oleh Mitra 2.

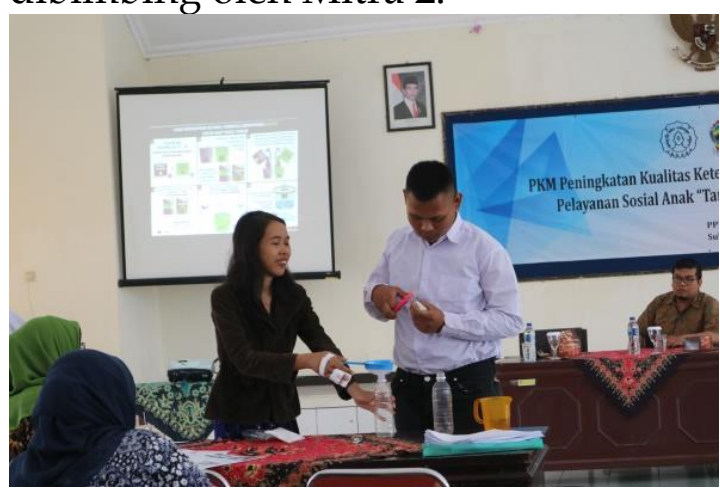

Gambar 8. Praktik Formulasi Nutrisi

Tanam

Tim pengabdi juga menyerahkan TTG berupa stater kit Wick System dan Instalasi Hidroponik kepada pihak PPSA "Taruna Yodha" Sukoharjo. 


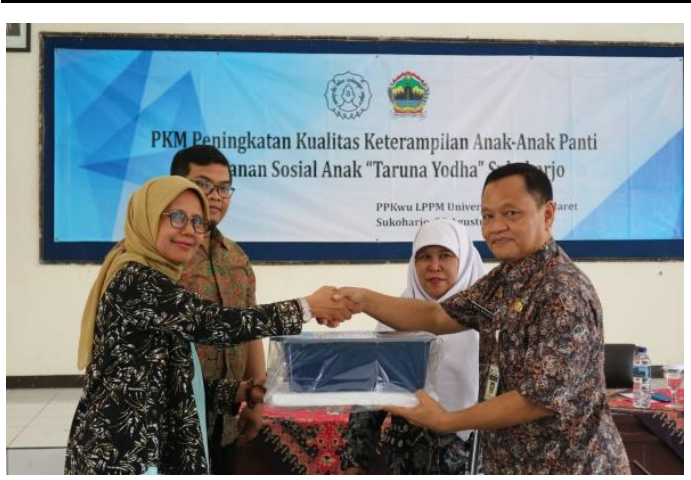

Gambar 9. Penyerahan Stater Kit Secara Simbolik

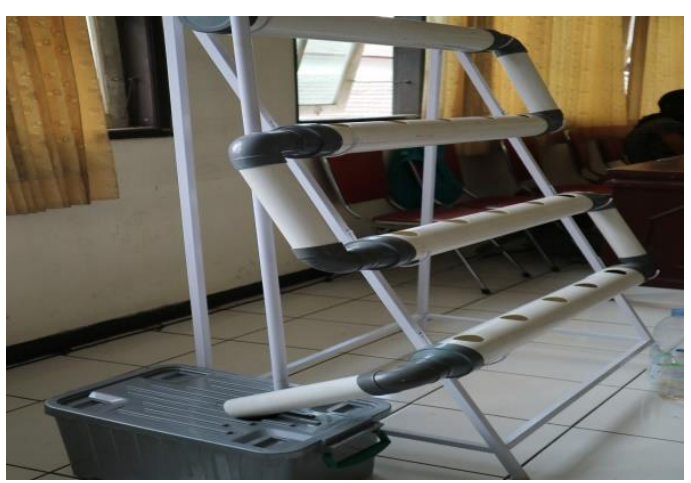

Gambar 10. Instalasi Hidroponik

Peserta juga memperoleh materi tentang teknik pemindahan bibit ke media tanam dari mitra 2. Bibit yang disediakan adalah bibit kangkung dan bibit sawi. Setiap siswa memperoleh kesempatan untuk mempraktikkan proses pemindahan benih dari loyang ke stater kit dan instalasi hidroponik yang telah disediakan. Antusiasme siswa sangat tinggi terhadap kegiatan ini. Hal ini dibuktikan dengan banyaknya pertanyaan terkait proses pemindahannya.

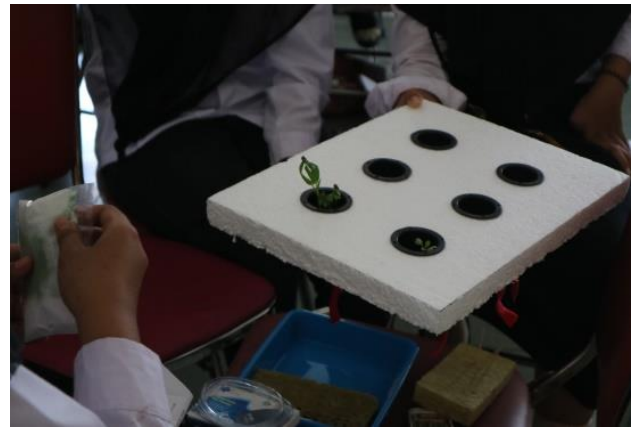

Gambar 11 Proses pemindahan bibit ke media tanam

\subsection{Monitoring Evaluasi}

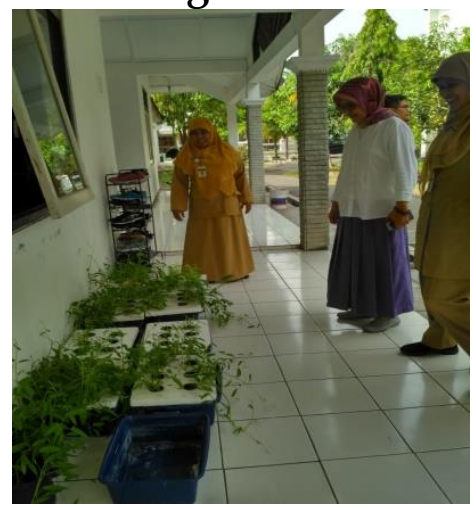

Gambar 12. Monitoring Evaluasi

Kegiatan monitoring evaluasi ini dilaksanakan pada tanggal 4 November 2018. Kegiatan monitoring ini diikuti oleh tim pengabdi, tim pemonev dari LPPM Universitas Sebelas Maret dan siswa PPSA "Taruna Yodha".

Hasil dari monitoring evaluasi terkait tanaman hidroponik yaitu mengenai tingkat kesuburan tanaman hidroponik. Terdapat beberapa tanaman yang kurang subur yang disebabkan oleh beberapa faktor, antara lain sebagai berikut:

a. Kurangnya nutrisi dan sinar matahari. Kebanyakan tanaman hidroponik diletakkan ditempat yang kurang sinar matahari.

b. Kurangnya Sirkulasi udara karena cuaca pada saat itu panas. 
c. Kurang tepatnya cara panen. Cara panen yang tepat adalah dengan mencabut seluruh akarnya. Selama ini cara panen yang dilakukan adalah dengan memotong batang sayur dan meninggalkan akar.

d. Kurang berkalanya penggantian air sebagai media tanam. Penggantian air seharusnya dilakukan 2-3 hari sekali.

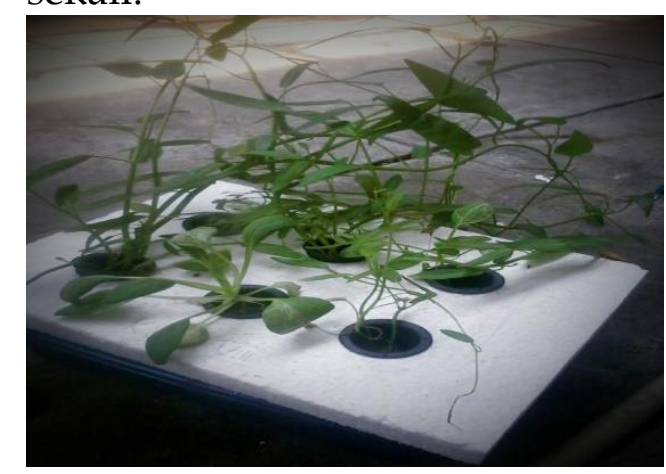

Gambar 13. Tanaman yang kurang subur

Namun ada juga hasil tanam hidroponik yang tumbuh subur. Ketika tim pengabdi berkunjung ke sana, tim pengabdi ikut memanen kangkung yang tumbuh subur. Hasil panen tanaman hidroponik ini dimanfaatkan oleh pihak PPSA Taruna Yodha Sukoharjo untuk membantu memenuhi kebutuhan sayur di Panti. Sehingga dapat mengurangi sedikit beban belanja sayur mayur di PPSA Taruna Yodha. Harapan kedepan agar bisa dikelola lebih baik lagi sehingga mendatangkan penghasilan dari bercocok tanam hidroponik dan dapat meningkatkan kualitas keterampilan bagi anak-anak PPSA "Taruna Yodha" Sukoharjo sehingga nanti dapat digunakan sebagai bekal diri dalam mengembangkan diri setelah lulus

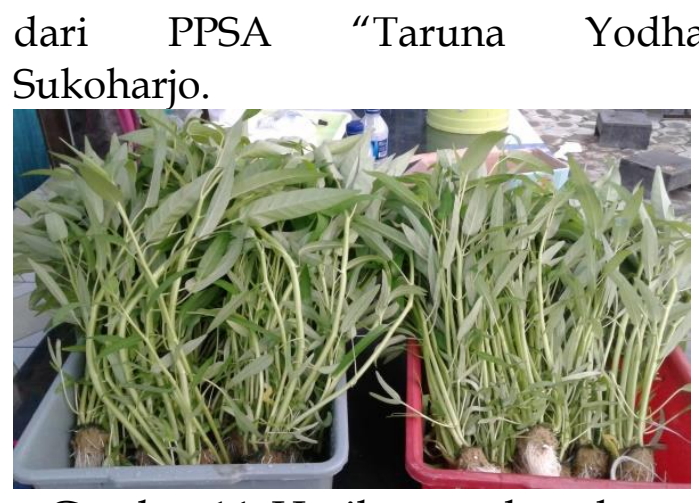

Gambar 14 Hasil panen kangkung

\section{KESIMPULAN}

Kegiatan pengabdian di PPSA "Taruna Yodha" yang telah dilakukan dapat berjalan dengan lancar. Kegiatan yang sudah terlaksana antara lain adalah koordinasi pelaksanaan kegiatan secara intern dengan tim pengabdi dan pihak PPSA "Taruna Yodha" Sukoharjo, pelatihan in-class, serta penyerahan TTG berupa Stater Kit dan instalasi hidroponik serta monitoring evaluasi.

Peserta pelatihan sangat antuasias dalam mengikuti rangkaian kegiatan pengabdian dari awal hingga akhir. Berdasarkan hasil evaluasi monitoring, terdapat ada beberapa kendala yang menyebabkan tanaman hidroponik kurang tumbuh subur. PPSA Taruna Yodha memanfaatkan hasil panen tanaman hidroponik untuk mencukupi kebutuhan sayursayuran di panti, sehingga dapat sedikit mengurangi biaya belanja sayur mayur. Dengan demikian dapat disimpulkan bahwa:

1. Pelatihan ini dapat meningkatkan kualitas keterampilan anak-anak PPSA “Taruna Yodha" Sukoharjo, yaitu keterampilan bercocok tanam hidroponik, sehingga nanti dapat digunakan sebagai bekal dalam 
mengembangkan diri setelah lulus dari PPSA "Taruna Yodha" Sukoharjo.

2. Pelatihan ini meningkatkan motivasi anak-anak PPSA untuk menjadi wirausaha setelah mereka lulus, sebanyak 8\% anak-anak memiliki motivasi yang sangat tinggi, dan 85\% menunjukkan motivasi berwirausaha tinggi.

3. Pelatihan ini secara tidak langsung dapat menambah pendapatan dalam bentuk hasil panen tanaman hidroponik. Dalam jangka panjang, jika sarana bercocok tanam tanaman hidroponik dikembangkan akan dapat menambah pendapatan yang lebih besar.

4. Pelatihan ini menambah pangsa pasar mitra PPKwu, karena untuk menjaga keberlanjutan program ini, PPSA "Taruna Yudha" dimungkinkan akan menambah sarana prasarana hidroponik. Selain itu, bagi anak-anak alumni yang akan bercocok tanam hidroponik setelah lulus mereka dapat bermitra dengan Tarinble Hydrofarm.

\section{DAFTAR PUSTAKA}

Badan Pusat Statistik Jawa Tengah. [14 Februari 2018]. https://jateng.bps.go.id/staticta ble/2017/11/02/1665/persentas e-penduduk-usia-7-24-tahunmenurut-jenis-kelaminkelompok-umur-sekolah-danpartisipasi-sekolah-di-provinsijawa-tengah-2015---2016.html

Chelluz Pahun. 10 Besar Daerah dengan Kasus Putus Sekolah
Tertinggi.[13 Februari 2018]. Tersedia dari: https://chelluzpahun.wordpress .com/2012/06/04/10-besardaerah-dengan-kasus-putussekolah-tertinggi/

Satu Data Indonesia. Data Putus Sekolah. [14 Februari 2018]. Tersedia dari: http:/ / data.go.id/dataset/siswa -sekolah-menengah-pertamayang-putussekolah/resource/5fe7f569-26164370-b6a4-e50da0597ff2

Toko Mesin Maksindo. Peluang Bisnis Tanaman Hidroponik dan Analisa Usaha. [14 Februari 2018]. Tersedia dari: http://www.tokomesin.com/pe luang-bisnis-tanamanhidroponik-dan-analisausahanya.html 